\title{
Productivity and Irrigation Water Use Efficiency of Sewi Date Palm under Different Irrigation System
}

\author{
S. Hosny Samia, M. F. El-Kholy, H. Khairy, and E. A. Madboly
}

\section{ABSTRACT}

This work was carried out during three successive seasons of 2018, 2019 and 2020 on Sewi date palm grown on sandy soil in a private farm at El-Baharia Oasis, Giza Governorate, Egypt, $\left(28^{\circ} 1^{\prime} 1^{\prime} 0^{\prime \prime}\right.$ N: $28^{\circ} 57^{\prime} 35^{\prime \prime}$ E. 130 m a.s.l. $)$ to evaluate the effectiveness of irrigation water levels $(100,80$ and $60 \%$ IR) under different irrigation system (drip and bubbler) on growth, yield, fruit quality and irrigation water use efficiency. Results showed that the studied quality parameters (except the soluble solid content (S.S.C.) of the date palm fruits were highest under the DIS, IR=100\% for the tested seasons. Data referred to all the studied properties significantly affected with increasing water supply under any irrigation system. Used drip irrigation system led to produce good quality compared with bubbler ones. Evaluation of drip irrigation system with $100 \%$ of IR enhanced yield and improved irrigation water use efficiency in the three tested seasons. Thus, this study recommends using the DIS, IR=100 \% to irrigate date palm trees under El-Baharia Oasis conditions

Keywords: bubbler irrigation, drip irrigation, Irrigation Requirement (IR), irrigation water use efficiency, Sewi date palm, yield.
Submitted : December 07, 2021

Published : January 13, 2022

ISSN: $2684-1827$

DOI: 10.24018 /ejfood.2022.4.1.433

\section{S. Hosny Samia}

Tropical fruits Res. Dep., Horticulture Research Institute, Agricultural Research Center, Egypt.

(e-mail: samiasalah71@gmail.com)

M. F. El-Kholy

Tropical fruits Res. Dep., Horticulture Research Institute, Agricultural Research Center, Egypt.

H. Khairy

Tropical fruits Res. Dep., Horticulture

Research Institute, Agricultural Research Center, Egypt.

E. A. Madboly

Center lab. for Date Palm Res. and Dev., Agricultural Research Center, Egypt.

*Corresponding Author

\section{INTRODUCTION}

Water deficiency is a major constraint in arid and semi-arid regions. Crops that require less irrigation water and those, which are considered drought-tolerant such as date palm (Phoenix dactylifera L.), are dominant in these regions [1]. In date palm tree the root zone depth is ranging between $1.5 \mathrm{~m}$ to $2.5 \mathrm{~m}$, the tree could uptake $65 \%$ to $80 \%$ of water within a root zone depth not exceeding 1.2 meter [2]. Date palm is a large tree, and its water requirements is comparatively high, it's consumption vary from area to another, due to many factors, mainly climate and soil, however, the annual water requirements for a mature date palm may range between 115 and 306 cubic meters [3]. Reservation of water and maximization of water use efficiency in arid and semi-arid regions through modern irrigation technologies have become key for sustainable crop production. Although highest date palm production is achieved when providing full irrigation water requirements by traditional methods, the same production can be achieved with significantly less water application, up to $50 \%$ less, by using modern irrigation systems [4]. The optimum date palm response to drip irrigation is due to the nature of the system where water is delivered in a slow process for relatively long period of time through drippers, this process provides better control and distribution for water through soil profile to an extent that, losses due to evaporation and deep percolation reduced to the minimum, therefore, date palm tree could make use of almost all water delivered. Comparison between water use efficiencies for various irrigation methods (drip, basin, and bubbler) on date palms have shown that the drip system the highest water use efficiency followed by the basin system then the bubbler irrigation system [5]. It is necessary to control irrigation water through some water conservation methods, such as modern irrigation systems (trickle and bubbler). In a comparison study between traditional drip and bubbler irrigation systems on date palms, it was noted that, an accumulation of salts on the surface layer were higher for drip compared to bubbler system [6]. The date palm needs sufficient water of acceptable quality to enable it to reach its full yield potential. The uniformity of distribution of bubbler system was low, with an average of $62 \%$. Comparison with drip irrigation system have shown high water distribution performance with an average of $97 \%$ emission uniformity. The reasons for the low performance of bubblers were discussed and some recommendations were made to improve the bubbler system network [7].

The objectives of this study were to determine the optimum growth, yield, and water use- efficiency as affected by irrigation system (drip and bubbler irrigation systems) and irrigation requirements (recommended regime 100\%, 80\% from recommended regime and $60 \%$ from recommended 
regime) of Sewi date palm.

\section{MATERIALS AND METHODS}

The present study was conducted in a private farm at ElBaharia Oasis, Giza Governorate, Egypt, at $\left(28^{\circ} 19^{\prime} 10^{\prime \prime} \mathrm{N}\right.$ : $28^{\circ} 57^{\prime} 35^{\prime \prime}$ E. $130 \mathrm{~m}$ a.s.1.) in a sandy soil during three successive seasons 2018, 2019 and 2020 on 8 years old of Sewi date palm planted with $7 \times 7 \mathrm{~m}$. The experimental soil (is sandy) in texture and deficient in fertility according to mechanical and chemical analysis by [8], [9] as shown in Tables I.

The experiment was designed to evaluate two irrigation systems of microirrigation (drip and bubbler) imposed upon the levels of $100 \%, 80 \%, 60 \%$ from ETo of water regimes. The drip (trickle) system with two lines per single now and promising micro-flapper emitters was used. One dripper $100 \mathrm{~cm}$. discharge 4 liter/hour). The bubbler system with two lines per single now and promising was used. (One bubbler discharge 25 liter/hour. Thus, experimental consisted of six treatment each treatment was represented by three replicates, each of three palms.

Semi-dry dates of the Siwi variety were irrigated using three water regime treatments under two irrigation systems [drip irrigation system (DIS) and bubbler irrigation system (BIS).] were investigated under the current study. The first water regime (W1) received $100 \%$ of the date palm water requirement which was calculated by Penman-Monteith equation for dry land conditions as [10]. The second and third (W2, W3) received 80 and $60 \%$ of the date palm water requirement, respectively. W1 was considered a control because it receives the complete water requirement and the maximum amount that can be afforded under the conditions of the experimental area

\section{A. Reference Evapotranspiration (ETo)}

ETo values were calculated based on local meteorological data of the experimental site Table II and according to the Penman-Monteith equation [11] calculations were performed using the CROPWAT model.

Estimation of Irrigation Water Requirements for date palm using weather parameters are incorporated into the ETo multiplying the reference crop Evapotranspiration, ETo, by a crop coefficient, Kc according to FAO [9], the same (methodology was adopted by many studies [8], [11].

$$
\mathrm{IR}=\mathrm{Kc} \times \mathrm{ETo} \times \mathrm{LF} \times \mathrm{IE} \times \mathrm{R} \times \text { Area }(\mathrm{fed}) / 1000
$$

where:

$\mathrm{IR}=$ Irrigation requirements $(\mathrm{m} / \mathrm{fed})$.

$\mathrm{Kc}=$ Crop coefficient [0.40-0.80] according to [12] and [13]

$\mathrm{ETo}=$ Reference crop Evapotranspiration (mm/day).

$\mathrm{LF}=$ Leaching fraction (assumed $20 \%$ of irrigation water).

$\mathrm{IE}=$ Irrigation efficiency of the irrigation system in the field (assumed 85\%).

$\mathrm{R}=$ Reduction factor $(35-70 \%$ cover in this study).

Area $=$ The irrigated area $\left(\right.$ one feddan $=4200 \mathrm{~m}^{2}$ ).

$1000=$ To convert from $\mathrm{mm}$ to cubic meter $(\mathrm{m})$.

The following parameters were used to evaluate the tested treatments:

The leaf length $(\mathrm{cm})$, leaflet length $(\mathrm{cm})$, leaflet width $(\mathrm{cm})$, yield per palm $(\mathrm{kg})$, fruit weight $(\mathrm{g})$, fruit quality, total soluble solid (TSS) content, total acidity \%, Total tannins $(\%)$, total sugar $\%$, reducing and non-reducing sugar and irrigation water-use efficiency (IWUE) $\mathrm{kg} \mathrm{m}^{-3}$ were recorded and tabulated.

TABLE I: PHYSICAL AND CHEMICAL PROPERTIES OF REPRESENTATIVE COMPOSITE SOIL SAMPLE FROM THE FIELD EXPERIMENTAL SITE

\begin{tabular}{|c|c|c|c|c|c|c|c|c|c|}
\hline \multicolumn{10}{|c|}{ Physical properties of the soil } \\
\hline $30-60$ & 23.3 & 60.6 & 10.9 & $5 . .2$ & Sandy & 0.46 & 12.5 & 3.32 & 9.34 \\
\hline \multicolumn{10}{|c|}{ Chemical properties of the soil } \\
\hline \multirow{2}{*}{ Soil depth } & \multirow{2}{*}{$\mathrm{EC}$} & \multirow{2}{*}{ PH } & \multirow{2}{*}{$\mathrm{CaCO}_{3}$} & CEC & \multicolumn{5}{|c|}{ Soluble ions $(\mathrm{meq} / \mathrm{l})$ in saturated soil } \\
\hline & & & & mole/kg & $\mathrm{SO}_{4}^{--}$ & $\mathrm{CL}^{-}$ & $\mathrm{HCO}_{3}$ & $\mathrm{Na}^{+}$ & $\mathrm{Mg}^{++}$ \\
\hline $30-60$ & 4.55 & 7.51 & 4.85 & 8.29 & 22.7 & 17.6 & 2.26 & 20.1 & 9.6 \\
\hline $60-90$ & 3.85 & 7.59 & 3.27 & 8.51 & 20.3 & 15.89 & 2.02 & 18.5 & 8.96 \\
\hline
\end{tabular}

TABLE II: DOORENBOS-PRUITT FORMULA AND METEOROLOGICAL DATA

\begin{tabular}{|c|c|c|c|c|c|c|c|c|c|}
\hline \multirow{2}{*}{ Month } & \multirow{2}{*}{$\mathrm{Kc}$} & \multicolumn{2}{|l|}{ (ETo) } & \multicolumn{6}{|c|}{ Meteorological data } \\
\hline & & $\mathrm{mm} /$ day & $\mathrm{mm} / \mathrm{month}$ & T. $\max$ & T. $\min$ & W.S. & R.H. & S.S. & R.F. \\
\hline Jan. & 0.75 & 3.14 & 97.3 & 17.10 & 4.40 & 3.00 & 48.20 & 11.00 & 1.50 \\
\hline Feb. & 0.80 & 3.81 & 106.7 & 19.40 & 6.20 & 2.90 & 46.60 & 11.00 & 1.83 \\
\hline Mar. & 0.85 & 5.34 & 165.5 & 22.80 & 8.40 & 3.40 & 40.40 & 11.80 & 0.44 \\
\hline Apr. & 0.93 & 6.98 & 209.4 & 27.90 & 12.70 & 3.30 & 32.70 & 12.80 & 0.22 \\
\hline May & 0.95 & 7.76 & 240.6 & 35.60 & 18.70 & 3.30 & 22.00 & 13.50 & 0.00 \\
\hline Jun. & 1.00 & 9.88 & 296.4 & 37.20 & 22.10 & 3.60 & 29.00 & 13.90 & 0.00 \\
\hline Jul. & 1.00 & 9.70 & 300.7 & 38.10 & 22.90 & 3.40 & 30.30 & 13.80 & 0.00 \\
\hline Aug. & 1.00 & 8.82 & 273.4 & 37.50 & 22.50 & 3.10 & 31.40 & 13.00 & 0.00 \\
\hline Sep. & 0.90 & 7.57 & 227.1 & 34.30 & 20.00 & 3.40 & 40.80 & 12.20 & 0.00 \\
\hline Oct. & 0.85 & 5.92 & 183.5 & 31.90 & 18.10 & 2.80 & 41.10 & 11.30 & 1.46 \\
\hline Nov. & 0.80 & 4.17 & 125.1 & 26.80 & 13.30 & 2.30 & 45.60 & 10.50 & 0.00 \\
\hline Dec. & 0.75 & 2.89 & 89.6 & 19.60 & 7.90 & 3.10 & 62.80 & 10.10 & 20.36 \\
\hline Total & & & 2315 & & & & & & \\
\hline
\end{tabular}

Where: T. $\max$, T. min= maximum and minimum temperature ${ }^{\circ} \mathrm{C}$; W.S. =wind speed $(\mathrm{m} / \mathrm{sec})$; R.H.= relative humidity $(\%)$; S.S.= actual sun shine (hour) R.F=rainfall(mm/month).

[Data were obtained from the agrometeorological Unit at SWERI, ARC]. 
TABLE III: MONTHLY APPLIED IRRIGATION WATER TO PALM TREES UNDER THE TWO IRRIGATION SYSTEM

\begin{tabular}{|c|c|c|c|c|c|c|c|c|c|c|c|c|}
\hline \multirow{4}{*}{ Month } & \multicolumn{12}{|c|}{ Irrigation systems } \\
\hline & \multicolumn{6}{|c|}{ Drip Irrigation } & \multicolumn{6}{|c|}{ Bubbler Irrigation } \\
\hline & \multicolumn{2}{|c|}{$100 \% \mathrm{ETc}$} & \multicolumn{2}{|c|}{$80 \%$ ETc } & \multicolumn{2}{|c|}{$60 \%$ Etc } & \multicolumn{2}{|c|}{$100 \%$ Etc } & \multicolumn{2}{|c|}{$80 \%$ ETc } & \multicolumn{2}{|c|}{$60 \%$ ETc } \\
\hline & $\begin{array}{c}\text { L/tree/ } \\
\text { Day }\end{array}$ & $\begin{array}{c}\mathrm{m}^{3} / \mathrm{fed} / \\
\text { month }\end{array}$ & $\begin{array}{c}\text { L/tree/ } \\
\text { day }\end{array}$ & $\begin{array}{c}\mathrm{m}^{3} / \mathrm{fed} / \\
\text { month }\end{array}$ & $\begin{array}{c}\text { L/tree/ } \\
\text { Day }\end{array}$ & $\begin{array}{c}\mathrm{m}^{3} / \mathrm{fed} / \\
\text { month }\end{array}$ & $\begin{array}{c}\text { L/tree/ } \\
\text { Day }\end{array}$ & $\begin{array}{c}\mathrm{m}^{3} / \mathrm{fed} / \\
\text { month }\end{array}$ & $\begin{array}{c}\text { L/tree/ } \\
\text { day }\end{array}$ & $\begin{array}{c}\mathrm{m}^{3} / \mathrm{fed} / \\
\text { month }\end{array}$ & $\begin{array}{c}\text { L/tree/ } \\
\text { day }\end{array}$ & $\begin{array}{l}\mathrm{m}^{3} / \mathrm{fed} / \\
\text { month }\end{array}$ \\
\hline Jan. & 91.6 & 187 & 73.3 & 150 & 54.9 & 112 & 103 & 211 & 82.4 & 169 & 61.8 & 127 \\
\hline Feb. & 118.5 & 219 & 94.8 & 175 & 71.1 & 132 & 133.4 & 246 & 106.7 & 197 & 80.1 & 147 \\
\hline Mar. & 176.5 & 361 & 141.2 & 289 & 105.9 & 217 & 198.6 & 406 & 158.9 & 325 & 119.2 & 244 \\
\hline Apr. & 252.4 & 500 & 202 & 400 & 151.5 & 300 & 284 & 562 & 227.2 & 450 & 170.2 & 338 \\
\hline May & 286.7 & 587 & 229.4 & 469 & 172 & 352 & 322.5 & 660 & 258 & 528 & 193.5 & 396 \\
\hline Jun. & 384.2 & 761 & 307.4 & 609 & 230.6 & 457 & 432.3 & 856 & 645.8 & 685 & 259 & 514 \\
\hline Jul. & 377.2 & 772 & 301.8 & 617 & 226.4 & 463 & 424.4 & 868 & 339.5 & 695 & 254.6 & 521 \\
\hline Aug. & 343 & 702 & 274.4 & 561 & 205.8 & 420 & 385.9 & 790 & 308.7 & 632 & 231.5 & 474 \\
\hline Sep. & 265 & 525 & 212 & 420 & 159 & 315 & 298.1 & 590 & 238.5 & 472 & 178.9 & 354 \\
\hline Oct. & 195.7 & 400 & 156.6 & 320 & 117.4 & 240 & 220.2 & 450 & 176.1 & 360 & 132.1 & 270 \\
\hline Nov. & 129.7 & 257 & 103.8 & 205 & 77.8 & 154 & 146 & 289 & 116.8 & 231 & 87.6 & 172 \\
\hline Dec. & 84.3 & 173 & 67.4 & 138 & 50.6 & 104 & 94.8 & 194 & 75.9 & 155 & 56.9 & 116 \\
\hline Total & & 5444 & & 4353 & & 3266 & & 6122 & & 4899 & & 3673 \\
\hline
\end{tabular}

\section{B. Statistical Analysis}

A split plot design in 3 replicates was followed as experimental design where irrigation system put in sub-main plots and irrigation levels in main plot. The experimental data were tabulated and statistically analyzed according to Snedecor and Cochran [14] and the differences between mean various treatments were compared by using New L.S.D. at $5 \%$ level of probability [15].

\section{RESULTS AND DISCUSSION}

\section{A. Leaf Length and Leaflet (Length and Width)}

Data in Table IV clearly show that the studied leaf length $(\mathrm{cm})$ and leaflet (length and width) of Sewi date palm increased as the IR increased for all treatments. The leaf properties significantly affected with increasing water supply under any irrigation system. The results showed nonsignificant effect between $100 \%$ and $80 \%$ IR at the studied seasons. The highest value of leaf length was 582, 582and $583 \mathrm{~cm}$ obtained by using the highest IR $(100 \%)$ in drip irrigation system in the studied seasons respectively. Leaf length was increased in drip system as compared with bubbler one $(582,582.3,583 \mathrm{~cm}$, against $454.3,457.3,457.3 \mathrm{~cm})$ in tested seasons.

As for, the longest value of leaflet length was noticed with the highest quantity of water under any irrigation system. The highest value of leaflet length was $72.75,72.8$ and $72.7 \mathrm{~cm}$ obtained by using the highest IR $(100 \%)$ in drip irrigation system in the studied seasons respectively. Leaf length was increased in drip system as compared with bubbler one $(71.62,71.83,71.73 \mathrm{~cm}$, against 56.7, $56.7,56.7 \mathrm{~cm})$ in tested seasons. The shortest leaflet length was show with IR at the rate $60 \%$ under any irrigation systems. Concerning of leaflet width, the highest value was 3.96, 3.97 and $3.96 \mathrm{~cm}$ obtained by using the highest IR (100\%) in drip irrigation system in the studied seasons respectively. Leaflet width was increased in drip system as compared with bubbler one (3.9, 3.92, 3.91 $\mathrm{cm})$, against $(3.0,3.2,3.1 \mathrm{~cm})$ in tested seasons.

Longest values were $(3.96,3.96,3.96 \mathrm{~cm})$ with the $(100 \%)$ IR under drip irrigation. Whereas the shortest value was (2.9, $3.1,3.0 \mathrm{~cm})$ with the $(60 \%)$ IR under bubbler irrigation system.

All previous mentioned growth parameters of date palm tended to increase by increasing amounts of applying water among any irrigation system. Thus, it can be concluded that, the active photosynthesis net assimilation relative growth rates affected by the amount of water [16]. Roots extended horizontally by $0.60 \mathrm{~m}$ under a surface drip irrigation system, by $1 \mathrm{~m}$ with traditional surface irrigation and by $1.75 \mathrm{~m}$ with the DIS [17]. This may be due to the fact that, drip irrigation system provided the crop with adequate water requirement at the root zone due to their high performance and efficiency. The result agrees with the result obtained [18].

\begin{tabular}{|c|c|c|c|c|c|c|c|c|c|}
\hline \multirow{3}{*}{$\begin{array}{l}\text { Irr. requirement } \\
\mathrm{m}^{3} . / \text { Fed/year }\end{array}$} & \multicolumn{9}{|c|}{ Leaf length $(\mathrm{cm})$} \\
\hline & \multicolumn{3}{|c|}{ Irr.syst $\left(1^{\text {st }}\right)$} & \multicolumn{3}{|c|}{ Irr.syst $\left(2^{\text {nd }}\right)$} & \multicolumn{3}{|c|}{ Irr.syst $\left(3^{\text {th }}\right)$} \\
\hline & Bub. & Drip & Mean(B) & Bub. & Drip & Mean(B) & Bub. & Drip & Mean(B) \\
\hline $100 \%$ & 464 & 582 & 523 & 464 & 582.3 & 523.15 & 464 & 583 & 523.5 \\
\hline $80 \%$ & 456 & 580.7 & 518.35 & 463 & 581 & 522 & 462 & 581.1 & 521.55 \\
\hline $60 \%$ of & 443 & 559 & 501 & 445 & 561 & 503 & 446 & 560.2 & 503.1 \\
\hline Mean (A) & 454.3 & 573.9 & & 457.3 & 574.8 & & 457.3 & 574.8 & \\
\hline \multirow[t]{2}{*}{ New L.S.D. at 0.05} & \multicolumn{3}{|c|}{$\begin{array}{c}\mathrm{A}=1.804 \mathrm{~B}=1.835 \\
\mathrm{~A} \times \mathrm{B}=2.559\end{array}$} & \multicolumn{3}{|c|}{$\begin{array}{c}\mathrm{A}=1.225 \mathrm{~B}=1.284 \\
\mathrm{~A} \times \mathrm{B}=1.816\end{array}$} & \multicolumn{3}{|c|}{$\begin{array}{c}\mathrm{A}=1.868 \mathrm{~B}=1.901 \\
\mathrm{~A} \times \mathrm{B}=2.691\end{array}$} \\
\hline & \multicolumn{9}{|c|}{ Leaflet length $(\mathrm{cm})$} \\
\hline $100 \%$ & 58 & 72.8 & 65.4 & 58 & 72.8 & 65.4 & 58 & 72.7 & 65.4 \\
\hline $80 \%$ & 57 & 72.2 & 64.6 & 57 & 72.6 & 64.8 & 57 & 72.5 & 64.8 \\
\hline $60 \%$ & 55 & 69.9 & 62.5 & 55 & 70.1 & 62.6 & 55 & 70 & 62.5 \\
\hline Mean $(\mathrm{A})$ & 56.7 & 71.6 & & 56.7 & 71.8 & & 56.7 & 71.7 & \\
\hline \multirow[t]{2}{*}{ New L.S.D. at 0.05} & \multicolumn{3}{|c|}{$\begin{array}{c}\mathrm{A}=0.0722 \mathrm{~B}=0.0815 \\
\mathrm{~A} \times \mathrm{B}=0.152\end{array}$} & \multicolumn{3}{|c|}{$\begin{array}{c}\mathrm{A}=0.0721 \mathrm{~B}=0.0822 \\
\mathrm{~A} \times \mathrm{B}=0.161\end{array}$} & \multicolumn{3}{|c|}{$\mathrm{A}=0.0733 \mathrm{~B}=0.0833 \mathrm{~A} \times \mathrm{B}=0.165$} \\
\hline & \multicolumn{9}{|c|}{ Leaflet width $\mathrm{cm}$ ) } \\
\hline $100 \%$ & 3.1 & 3.96 & 3.5 & 3.2 & 3.97 & 3.6 & 3.2 & 3.96 & 3.6 \\
\hline $80 \%$ & 3.1 & 3.93 & 3.5 & 3.2 & 3.96 & 3.6 & 3.2 & 3.95 & 3.6 \\
\hline $60 \%$ & 2.9 & 3.8 & 3.4 & 3.1 & 3.82 & 3.5 & 3 & 3.81 & 3.4 \\
\hline Mean (A) & 3.0 & 3.9 & & 3.2 & 3.9 & & 3.1 & 3.9 & \\
\hline New L.S.D. at 0.05 & \multicolumn{3}{|c|}{$\begin{array}{c}\mathrm{A}=0.015 \mathrm{~B}=0.016 \\
\mathrm{~A} \times \mathrm{B}=0.162\end{array}$} & \multicolumn{3}{|c|}{$\begin{array}{c}\mathrm{A}=0.088 \mathrm{~B}=0.097 \\
\mathrm{~A} \times \mathrm{B}=0.138\end{array}$} & \multicolumn{3}{|c|}{$\begin{array}{c}\mathrm{A}=0.021 \mathrm{~B}=0.018 \\
\mathrm{~A} \times \mathrm{B}=0.153\end{array}$} \\
\hline
\end{tabular}




\section{B. Yield}

Number of bunches/palms, yield/palm $(\mathrm{kg})$ and yield /fed. (ton) significantly varied according to the irrigation system and irrigation requirements. Data in Table V showed all parameters above were increased with increasing IR for all treatments. The data revealed that the drip irrigation system (DIS) was significantly superior to the bubbler (BIS) for all treatments. The highest number of bunches/palm were (21, 20 and 21) for the three tested seasons, respectively, as well as the highest yield /palm $(\mathrm{Kg})$ were $(181.7,206.7$ and $181.7 \mathrm{~kg}$ ), the highest yield/fed were (13.5, 13.4 and $13.5 \mathrm{ton})$ under the drip irrigation system and $100 \%$ IR.

These results may be attributed to the soil water distribution under the DIS, which was superior to that of the other systems. These results are consistent with [19], [20].

\section{Fruit Physical Properties}

Data in Table VI showed positive correlations occurred between irrigation systems and fruit physical properties. Data referred that drip irrigation system recorded the highest value compared with bubbler ones. In addition, data in Table VI show that fruit weight $(\mathrm{g})$, fruit length $(\mathrm{cm})$ and fruit diameter (cm) were significantly varied due to irrigation system and/or water amount in tested seasons. As such the highest values of fruit physical properties were noticed in palms irrigated with $100 \%$ IR treatment while the lowest values of physical properties were noticed in plants irrigated with $60 \%$ IR. The heaviest fruit were $(13.5 \& 13.5 \& 13.8 \mathrm{~g})$ the highest value of fruit length were $(4.84 \& 4.89 \& 4.87 \mathrm{~cm})$ and the highest value of fruit diameter were $(2.52 \& 2.72 \& 2.62 \mathrm{~cm})$ were obtained from palms received $100 \%$ IR under drip irrigation whilest the lightest ones of fruit weigh were $(8.9 \& 9.4 \& 10.2$ $\mathrm{g})$, the shortest fruit $(3.48 \& 3.66 \& 3.57 \mathrm{~cm})$, and narrow fruit were $(1.68 \& 1.75 \& 1.72 \mathrm{~cm})$ were obtained from palms irrigated with $60 \%$ IR under bubbler system in tested seasons, respectively.

These two irrigation systems seem to be enough to provide the palm trees with their water requirements. A similar trend was reported by [21]. Sometimes increasing water supply insignificantly increased date yield [22]. An additional possible explanation of these results is that drip irrigation offers better distribution of water in the soil. As a result, the root volume wetted beneath the surface is larger due to lateral movement of water, and the slow application and redistribution of soil water provide better soil aeration.

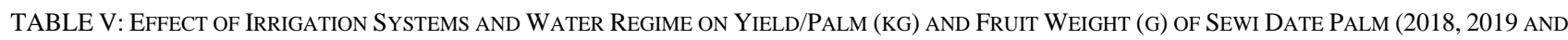

\begin{tabular}{|c|c|c|c|c|c|c|c|c|c|}
\hline \multirow{3}{*}{$\begin{array}{c}\text { Irr. } \\
\text { requirement } \\
\mathrm{m}^{3} . / \mathrm{Fed} / \text { year }\end{array}$} & \multicolumn{3}{|c|}{ No. of bunch } & \multicolumn{3}{|c|}{ Yield (kg/date palm) } & \multicolumn{3}{|c|}{ Yield (ton/fed.) } \\
\hline & Bub. & Drip & Mean (B) & Bub. & drip & Mean (B) & Bub. & Drip & Mean 180(B) \\
\hline & \multicolumn{9}{|c|}{ First season } \\
\hline $100 \%$ & 16 & 21 & 18.5 & 145.5 & 181.7 & 163.6 & 10.5 & 13.52 & 12.0 \\
\hline $80 \%$ & 14 & 18 & 16.0 & 126.6 & 158.3 & 142.5 & 8.9 & 11.16 & 10.0 \\
\hline $60 \%$ & 10 & 13.67 & 11.8 & 101.6 & 127 & 114.3 & 6.9 & 8.67 & 7.8 \\
\hline Mean (A) & 13.3 & 17.6 & & 124.6 & 155.7 & & 8.8 & 11.1 & \\
\hline \multirow{3}{*}{ New L.S.D. at 0.05} & \multirow{2}{*}{\multicolumn{3}{|c|}{$\begin{array}{c}\mathrm{A}=0.374 \mathrm{~B}=0.379 \\
\mathrm{~A} \times \mathrm{B}=0.537\end{array}$}} & \multirow{2}{*}{\multicolumn{3}{|c|}{$\begin{array}{c}\mathrm{A}=2.781 \mathrm{~B}=2.784 \\
\mathrm{~A} \times \mathrm{B}=3.937\end{array}$}} & \multirow{2}{*}{\multicolumn{3}{|c|}{$\begin{array}{c}\mathrm{A}=0.431 \mathrm{~B}=0.448 \\
\mathrm{~A} \times \mathrm{B}=0.633\end{array}$}} \\
\hline & & & & & & & & & \\
\hline & \multicolumn{9}{|c|}{ Second season } \\
\hline $100 \%$ & 16 & 20 & 18.0 & 164.5 & 206.7 & 185.6 & 10.7 & 13.43 & 12.1 \\
\hline $80 \%$ & 14 & 18 & 16.0 & 138.6 & 173.3 & 156.0 & 9 & 11.27 & 10.1 \\
\hline $60 \%$ & 10 & 13.67 & 11.8 & 108.8 & 136 & 122.4 & 7.1 & 8.84 & 8.0 \\
\hline Mean (A) & 13.3 & 17.2 & & 137.3 & 172.0 & & 8.9 & 11.2 & \\
\hline \multirow{3}{*}{ New L.S.D. at 0.05} & \multirow{2}{*}{\multicolumn{3}{|c|}{$\begin{array}{c}\mathrm{A}=0.355 \mathrm{~B}=0.363 \\
\mathrm{~A} \times \mathrm{B}=0.514\end{array}$}} & \multirow{2}{*}{\multicolumn{3}{|c|}{$\begin{array}{c}\mathrm{A}=2.918 \mathrm{~B}=2.923 \\
\mathrm{~A} \times \mathrm{B}=4.134\end{array}$}} & \multirow{2}{*}{\multicolumn{3}{|c|}{$\begin{array}{c}\mathrm{A}=0.462 \mathrm{~B}=0.478 \\
\mathrm{~A} \times \mathrm{B}=0.676\end{array}$}} \\
\hline & & & & & & & & & \\
\hline & \multicolumn{9}{|c|}{ Third season } \\
\hline $100 \%$ & 16 & 21 & 18.5 & 145.5 & 181.7 & 163.6 & 10.5 & 13.52 & 12.0 \\
\hline $80 \%$ & 14 & 18 & 16.0 & 126.6 & 158.3 & 142.5 & 8.9 & 11.16 & 10.0 \\
\hline $60 \%$ & 10 & 13.67 & 11.8 & 101.6 & 127 & 114.3 & 6.9 & 8.67 & 7.8 \\
\hline Mean (A) & 13.3 & 17.6 & & 124.6 & 155.7 & & 8.8 & 11.1 & \\
\hline New L.S.D. at 0.05 & \multicolumn{3}{|c|}{$\begin{array}{c}\mathrm{A}=0.374 \mathrm{~B}=0.379 \\
\mathrm{~A} \times \mathrm{B}=0.537\end{array}$} & \multicolumn{3}{|c|}{$\begin{array}{c}\mathrm{A}=2.781 \mathrm{~B}=2.784 \\
\mathrm{~A} \times \mathrm{B}=3.937\end{array}$} & \multicolumn{3}{|c|}{$\begin{array}{c}\mathrm{A}=0.431 \mathrm{~B}=0.448 \\
\mathrm{~A} \times \mathrm{B}=0.633\end{array}$} \\
\hline
\end{tabular}

TABLE VI: EFFECT OF IRRIGATION SYSTEMS AND WATER REGIME ON FrUIT PROPERTIES OF SEWI DATE PALM (2018, 2019 AND 2020 SEASONS)

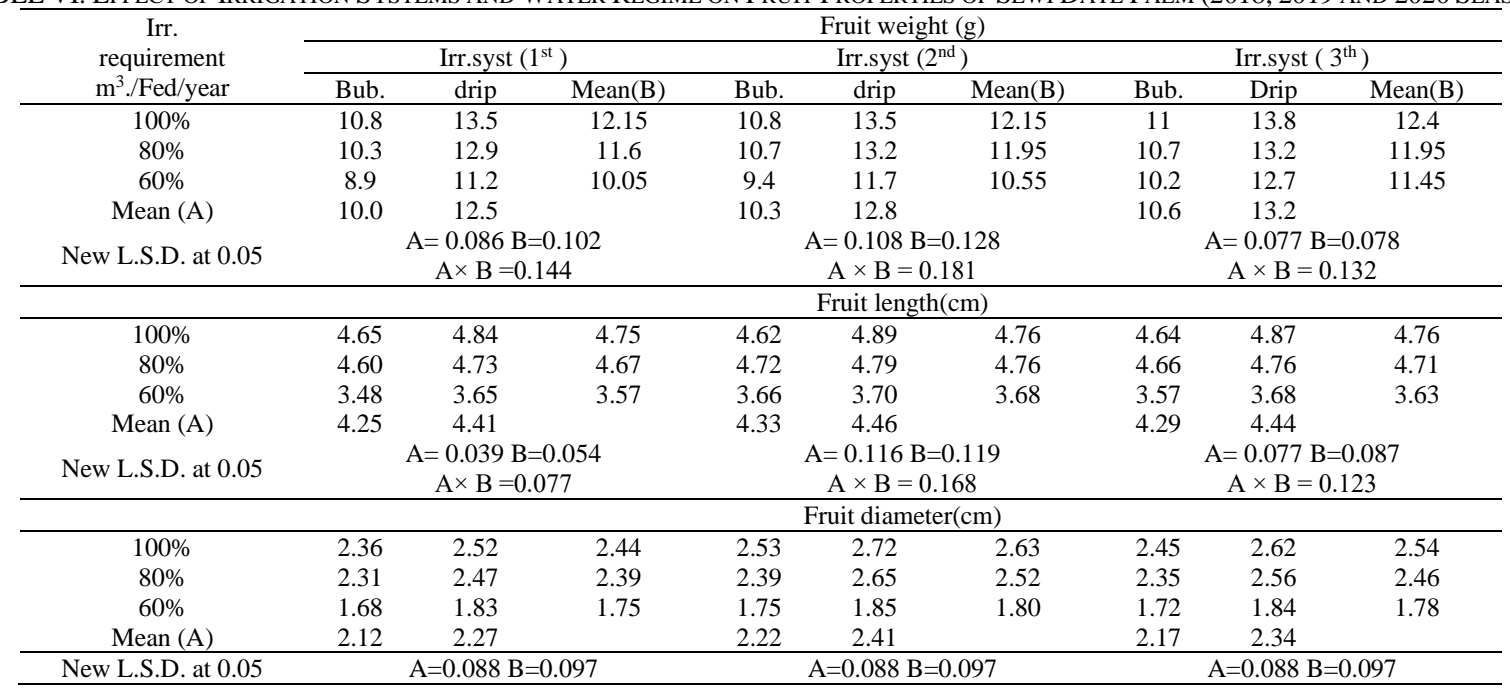




\section{Fruit Chemical Properties}

Data in Table VII showed non-significant effect in acidity or tannins in all treatments, except the S.S.C (\%) which decreased with increasing IR. The highest S.S.C were $(73.68$ $\& 73.25 \& 73.6)$ in three tested seasons respectively under drip irrigation system and $80 \%$ IR. These results are consistent with the findings of [14], [15].

Concerning of total sugar, reducing sugar, and nonreducing sugar data in Table VIII showed significantly varied due to irrigation system and irrigation water level in three tested seasons. As such the highest values of precedent parameters were noticed in palms irrigated with $100 \%$ IR treatment while the lowest values of flesh parameters were noticed in plants irrigated with $60 \%$ IR. The highest total sugar (68.8 \& $66.7 \& 67.8)$, reducing sugar $(57 \& 57.8 \&$ $58.1)$ and non-reducing sugar $(11.9 \& 8.8 \& 9.7)$ were obtained from palms received $100 \%$ IR under drip irrigation system in tested seasons, respectively.

\section{E. Irrigation Water Use Efficiency (IWUE)}

Recorded data (Table 9) proved that drip irrigation system gave the highest values compared with the bubbler ones. The highest value of I. W.U.E. for date palm fruits were 2.6, 2.7 and $2.6 \mathrm{~kg} \mathrm{~m}^{-3}$, respectively, under the DIS with $\mathrm{IR}=60 \%$ ETo. compared with all treatments. In other words, improvement of I.W.U.E. may be attributed with available water formed in the root zone, but not the amount of applied water. Interaction studies between the two main factors concerning W.U.E. to irrigation system and water quantity act dependently in this concern. These results may be attributed to the effects of deep drip irrigation which led to increased moisture with decreased water consumption. These results were similar to those reported [22]-[24].

TABLE VII: EFFECT OF IRRIGATION SySTEMS AND WATER REgIME ON S.S.C\%, ACIDITY \% AND TANNINS\% OF SEWI DATE PALM (2018, 2019 AND 2020 SEASONS)

\begin{tabular}{|c|c|c|c|c|c|c|c|c|c|}
\hline \multirow{3}{*}{$\begin{array}{c}\text { Irr. } \\
\text { requirement } \\
\mathrm{m}^{3} \text {./Fed/year }\end{array}$} & \multicolumn{9}{|c|}{ S.S.C (\%) } \\
\hline & \multicolumn{3}{|c|}{ Irr.syst $\left(1^{\text {st }}\right)$} & \multicolumn{3}{|c|}{ Irr.syst $\left(2^{\text {nd }}\right)$} & \multicolumn{3}{|c|}{ Irr.syst $\left(3^{\text {th }}\right)$} \\
\hline & Bub. & drip & $\operatorname{Mean}(\mathrm{B})$ & Bub. & Drip & $\operatorname{Mean}(\mathrm{B})$ & Bub. & Drip & Mean(B) \\
\hline $100 \%$ & 71.90 & 72.37 & 72.14 & 69.68 & 71.82 & 70.75 & 71.9 & 72.5 & 72.2 \\
\hline $80 \%$ & 72.81 & 73.68 & 73.25 & 72.16 & 73.25 & 72.71 & 72.9 & 73.6 & 73.25 \\
\hline $60 \%$ & 69.98 & 70.49 & 70.24 & 70.01 & 69.91 & 69.96 & 69.8 & 70.5 & 70.15 \\
\hline Mean (A) & 71.56 & 72.18 & & 70.62 & 71.66 & & 71.53 & 72.2 & \\
\hline New L.S.D. at & \multirow{2}{*}{\multicolumn{3}{|c|}{$\begin{array}{c}\mathrm{A}=0.528 \mathrm{~B}=0.542 \\
\mathrm{~A} \times \mathrm{B}=0.767\end{array}$}} & \multirow{2}{*}{\multicolumn{3}{|c|}{$\begin{array}{c}\mathrm{A}=0.549 \mathrm{~B}=0.562 \\
\mathrm{~A} \times \mathrm{B}=0.795\end{array}$}} & \multirow{2}{*}{\multicolumn{3}{|c|}{$\begin{array}{c}\mathrm{A}=0.077 \mathrm{~B}=0.087 \\
\mathrm{~A} \times \mathrm{B}=0.123\end{array}$}} \\
\hline \multirow[t]{2}{*}{0.05} & & & & & & & & & \\
\hline & \multicolumn{9}{|c|}{ Acidity $\%$} \\
\hline $100 \%$ & 0.379 & 0.322 & 0.351 & 0.247 & 0.314 & 0.280 & 0.388 & 0.357 & 0.373 \\
\hline $80 \%$ & 0.357 & 0.368 & 0.363 & 0.235 & 0.326 & 0.281 & 0.365 & 0.366 & 0.366 \\
\hline $60 \%$ & 0.338 & 0.345 & 0.342 & 0.231 & 0.305 & 0.268 & 0.346 & 0.325 & 0.336 \\
\hline Mean (A) & 0.358 & 0.345 & & 0.238 & 0.315 & & 0.366 & 0.349 & \\
\hline New L.S.D. at & \multirow{2}{*}{\multicolumn{3}{|c|}{$\begin{array}{c}\mathrm{A}=0.054 \mathrm{~B}=0.067 \\
\mathrm{~A} \times \mathrm{B}=0.094\end{array}$}} & \multirow{2}{*}{\multicolumn{3}{|c|}{$\begin{array}{c}\mathrm{A}=0.047 \mathrm{~B}=0.050 \\
\mathrm{~A} \times \mathrm{B}=0.071\end{array}$}} & \multirow{2}{*}{\multicolumn{3}{|c|}{$\begin{array}{c}\mathrm{A}=0.088 \mathrm{~B}=0.097 \\
\mathrm{~A} \times \mathrm{B}=0.138\end{array}$}} \\
\hline 0.05 & & & & & & & & & \\
\hline & \multicolumn{9}{|c|}{ Tannins $\%$} \\
\hline $100 \%$ & 0.137 & 0.143 & 0.140 & 0.140 & 0.143 & 0.142 & 0.138 & 0.139 & 0.138 \\
\hline $80 \%$ & 0.137 & 0.150 & 0.143 & 0.137 & 0.150 & 0.143 & 0.132 & 0.135 & 0.134 \\
\hline $60 \%$ & 0.163 & 0.170 & 0.167 & 0.170 & 0.160 & 0.165 & 0.152 & 0.159 & 0.156 \\
\hline Mean (A) & 0.146 & 0.154 & & 0.149 & 0.151 & & 0.141 & 0.144 & \\
\hline New L.S.D. at & \multirow{2}{*}{\multicolumn{3}{|c|}{$\begin{array}{c}\mathrm{A}=0.017 \mathrm{~B}=0.027 \\
\mathrm{~A} \times \mathrm{B}=0.039\end{array}$}} & \multirow{2}{*}{\multicolumn{3}{|c|}{$\begin{array}{c}\mathrm{A}=0.042 \mathrm{~B}=0.030 \\
\mathrm{~A} \times \mathrm{B}=0.042\end{array}$}} & \multirow{2}{*}{\multicolumn{3}{|c|}{$\begin{array}{c}\mathrm{A}=0.035 \mathrm{~B}=0.045 \\
\mathrm{~A} \times \mathrm{B}=0.0692\end{array}$}} \\
\hline 0.05 & & & & & & & & & \\
\hline
\end{tabular}

TABLE VIII: EFFECT OF IRRIGATION SYSTEMS AND WATER REGIME ON TOTAL SUGAR\%, REDUCING SUGAR\% AND NON-REDUCING SUGAR\% OF SEWI DATE PALM (2018, 2019 AND 2020 SEASONS)

\begin{tabular}{|c|c|c|c|c|c|c|c|c|c|}
\hline \multirow{7}{*}{$\begin{array}{c}\text { Irr. } \\
\text { requirement } \\
\mathrm{m}^{3} . / \text { Fed/year } \\
100 \% \\
80 \% \\
60 \% \\
\text { Mean (A) }\end{array}$} & \multicolumn{9}{|c|}{ Total sugars $\%$} \\
\hline & \multicolumn{3}{|c|}{ Irr.syst $\left(1^{\text {st }}\right)$} & \multicolumn{3}{|c|}{ Irr.syst $\left(2^{\text {nd }}\right)$} & \multicolumn{3}{|c|}{ Irr.syst $\left(3^{\text {th }}\right)$} \\
\hline & Bub. & drip & $\operatorname{Mean}(\mathrm{B})$ & Bub. & drip & $\operatorname{Mean}(\mathrm{B})$ & Bub. & Drip & Mean(B) \\
\hline & 68.84 & 68.88 & 68.86 & 66.70 & 66.70 & 66.70 & 67.3 & 67.8 & 67.6 \\
\hline & 66.45 & 67.20 & 66.68 & 67.40 & 67.67 & 67.54 & 65.9 & 66.2 & 66.05 \\
\hline & 66.30 & 66.90 & 66.75 & 68.16 & 68.17 & 68.16 & 64.2 & 65.3 & 64.75 \\
\hline & 67.20 & 67.66 & & 67.42 & 67.51 & & 65.8 & 66.43 & \\
\hline \multirow[t]{2}{*}{ New L.S.D. at 0.05} & \multicolumn{3}{|c|}{$\begin{array}{c}\mathrm{A}=0.507 \mathrm{~B}=0.512 \\
\mathrm{~A} \times \mathrm{B}=0.737\end{array}$} & \multicolumn{3}{|c|}{$\begin{array}{c}\mathrm{A}=0.434 \mathrm{~B}=0.451 \\
\mathrm{~A} \times \mathrm{B}=0.638\end{array}$} & \multicolumn{3}{|c|}{$\begin{array}{c}\mathrm{A}=0.328 \mathrm{~B}=0.351 \\
\mathrm{~A} \times \mathrm{B}=0.528\end{array}$} \\
\hline & \multicolumn{9}{|c|}{ Reducing sugars $\%$} \\
\hline $100 \%$ & 56.59 & 57.00 & 56.80 & 58.30 & 57.87 & 58.08 & 57.60 & 58.1 & 57.85 \\
\hline $80 \%$ & 57.38 & 57.73 & 57.56 & 57.54 & 57.41 & 57.48 & 58.1 & 58.8 & 58.45 \\
\hline $60 \%$ & 57.91 & 58.49 & 58.20 & 56.70 & 56.98 & 56.84 & 58.8 & 59.2 & 59.00 \\
\hline Mean (A) & 57.29 & 57.74 & & 57.51 & 57.42 & & 58.17 & 58.7 & \\
\hline \multirow[t]{2}{*}{ New L.S.D. at 0.05} & \multicolumn{3}{|c|}{$\begin{array}{c}\mathrm{A}=0.339 \mathrm{~B}=0.347 \\
\mathrm{~A} \times \mathrm{B}=0.490\end{array}$} & \multicolumn{3}{|c|}{$\begin{array}{c}\mathrm{A}=0.349 \mathrm{~B}=0.363 \\
\mathrm{~A} \times \mathrm{B}=0.514\end{array}$} & \multicolumn{3}{|c|}{$\begin{array}{c}\mathrm{A}=0.369 \mathrm{~B}=0.395 \\
\mathrm{~A} \times \mathrm{B}=0.566\end{array}$} \\
\hline & \multicolumn{9}{|c|}{ Non-reducing sugars \% } \\
\hline $100 \%$ & 12.25 & 11.88 & 12.06 & 8.4 & 8.83 & 8.62 & 9.7 & 9.7 & 9.75 \\
\hline $80 \%$ & 9.07 & 9.47 & 9.12 & 9.9 & 10.3 & 10.06 & 7.8 & 7.4 & 7.6 \\
\hline $60 \%$ & 8.39 & 8.41 & 8.55 & 11.5 & 11.2 & 11.32 & 5.4 & 6.1 & 5.75 \\
\hline Mean (A) & 9.91 & 9.92 & & 9.69 & 10.2 & & 7.63 & 7.73 & \\
\hline New L.S.D. at 0.05 & \multicolumn{3}{|c|}{$\begin{array}{c}\mathrm{A}=0.486 \mathrm{~B}=0.501 \\
\mathrm{~A} \times \mathrm{B}=0.708\end{array}$} & \multicolumn{3}{|c|}{$\begin{array}{c}\mathrm{A}=0.513 \mathrm{~B}=0.527 \\
\mathrm{~A} \times \mathrm{B}=0.745\end{array}$} & \multicolumn{3}{|c|}{$\begin{array}{c}\mathrm{A}=0.386 \mathrm{~B}=0.402 \\
\mathrm{~A} \times \mathrm{B}=0.705\end{array}$} \\
\hline
\end{tabular}


TABLE IX: EFFECT OF IRRIGATION SySTEMS AND WATER REGIME ON WATER USE EFFICIENCY (KG FRUIT/ M³) OF SEWI DATE PALM (2018, 2019 AND 2020 SEASONS)

\begin{tabular}{|c|c|c|c|c|c|c|c|c|c|}
\hline \multirow{3}{*}{$\begin{array}{c}\text { Irr. } \\
\text { requirement } \\
\mathrm{m}^{3} \text {./Fed/year }\end{array}$} & \multicolumn{9}{|c|}{ Water use efficiency ( $\mathrm{kg}$ fruit $\left./ \mathrm{m}^{3}\right)$} \\
\hline & \multicolumn{3}{|c|}{ Irr.syst $\left(1^{\text {st }}\right)$} & \multicolumn{3}{|c|}{ Irr.syst $\left(2^{\text {nd })}\right.$} & \multicolumn{3}{|c|}{ Irr.syst $\left(3^{\text {th }}\right)$} \\
\hline & Bub. & drip & Mean(B) & Bub. & drip & Mean(B) & Bub. & Drip & Mean(B) \\
\hline $100 \%$ & 1.7 & 2.4 & 2.05 & 1.74 & 2.46 & 2.10 & 1.71 & 2.48 & 2.10 \\
\hline $80 \%$ & 1.8 & 2.56 & 2.18 & 1.83 & 2.58 & 2.21 & 1.81 & 2.56 & 2.19 \\
\hline $60 \%$ & 1.8 & 2.65 & 2.23 & 1.9 & 2.71 & 2.31 & 1.87 & 2.65 & 2.26 \\
\hline Mean (A) & 1.8 & 2.5 & & 1.8 & 2.6 & & 1.8 & 2.6 & \\
\hline New L.S.D. at 0.05 & \multicolumn{3}{|c|}{$\begin{array}{c}\mathrm{A}=2.781 \mathrm{~B}=2.784 \\
\mathrm{~A} \times \mathrm{B}=3.937\end{array}$} & \multicolumn{3}{|c|}{$\begin{array}{c}\mathrm{A}=2.918 \mathrm{~B}=2.923 \\
\mathrm{~A} \times \mathrm{B}=4.134\end{array}$} & \multicolumn{3}{|c|}{$\begin{array}{c}\mathrm{A}=2.815 \mathrm{~B}=2.912 \\
\mathrm{~A} \times \mathrm{B}=3.972\end{array}$} \\
\hline
\end{tabular}

\section{CONCLUSION}

The results for the study showed that, all the studied properties significantly affected with increasing water supply under any irrigation system. Drip irrigation system led to produce good quality compared with bubbler ones. Evaluation of drip irrigation system with $100 \%$ of IR enhanced yield and improved irrigation water use efficiency in tested seasons. Thus, this study recommends using the DIS, $\mathrm{IR}=100 \%$ to cultivate date palm trees under El-Baharia Oasis conditions.

\section{ACKNOWLEDGMENT}

The authors wish to express his appreciation and gratitude to Prof.Doctor Tarek Ahmed (Soils, Water and Environment Res. Inst., Agric. Res. Center,) for help and constructive guidance throughout the course of the study.

\section{REFERENCES}

[1] AbdElgawad H.; Saleh A.M.; Al Jaouni S.; Selim S.; Hassan M.O.; Wadaan M.A.M.; Shuikan A.M.; Mohamed H.S.; Hozzein W.N Utilization of actinobacteria to enhance the production and quality of date palm (Phoenix dactylifera L.) fruits in a semi-arid environment. Sci. Total Environ. 2019;665, 690-697.

[2] Yaaqoob A. Date Palm Irrigation; Abstracted Review Article by: Achtrich W. (translation from German language). Bassel Al-Assad Journal for Agricultural Engineering Sciences, 1996;1(1):85-88. (in Arabic).

[3] Albaker A. Date Palm Trees. Ministry of Higher Education, Baghdad, Iraq, 1972, 225pages. (in Arabic)

[4] Food and Agriculture Organization of the United (FAO); International Center for Advanced Mediterranean Agronomic Studies (CIHEAM). Workshop on "Irrigation of Date Palm and Associated Crops" Faculty of Agriculture; Damascus University: Damascus, Syrian Arab Republic, ISBN 9789251059975, 2007.

[5] Al-Amoud A.I., Bacha M.A. and Al-Darby A.M. Seasonal Water Use of Date Palms in Central Region of Saudi Arabia. Agricultural Engineering Journal, 2000;9(2): 51-62.

[6] Nimah M. Localized versus drip irrigation system. Proceedings of the third drip irrigation congress, Fresno, California, USA., 1985, 52-554.

[7] Ahmed I Al-Amoud. Performance of bubbler irrigation system as compared to trickle for large size date palm tree farm. The Canadian Society for Bioengineering No. CSBE 08-172, pp 1-12, 2008.

[8] Page A.L.; Miller R.H. and Keeney D.R. Methods of soil analysis, part 2. Chemical and microbiological properties. Amer. Soc. of Agron, Madison, Wisconsin, USA, 1982.

[9] Klute A. Methods of soil analysis, Part (1). Physical and Mineralogical Methods-Agronomy monograph No. 9 (2nd Edition). ASA and SSSA, Madison, WI, USA: 635-660, 1986.

[10] Gafar KY. 2010. Improving the Penman-Monteith model of reference evapotaranspiration for arid climates. In Proceedings of the 15th International Conference on Meteorology and Sustainable Development, 23-25.

[11] FAO. Yield response to water. FAO Irrigation and Drainage paper No. 33 (Doorenbos J, KasamAH). Italy: Rome, 1979.
[12] Allen G.R., L.S. Pereira D. Raes and M. Smith. Crop evapotranspiration, guidelines for competing crop water requirements. FAO. Irrigation and drainages paper 56. Rome, Italy, 1998.

[13] Gafar K. Egyptian meteorological authority. International Meteorological Research Bulletin 24, 2009.

[14] Snedecor G.W. and W.G. Cochran. Statistical Methods. 6 The Iowa St. Univ., Press. Amer., Iowa. U.S.A., pp: 363-372, 1980.

[15] Waller P.A. and D.B. Duncan. A buyes rule for the symmetric multiple comparison problem. Amer State. Assoc. J., 1969;64:1484-1503.

[16] Ibrahim Y.M.; Saeed A.B. and Elamin A.W. Effect of irrigation water management on growth of date palm offshoots (Phoenix dactylifera) under the River Nile state conditions. University of Khartoum Journal of Agricultural Sciences, 2012; 20(3), 275-285.

[17] Bainbridge D.A. Deep pipe irrigation. The overstory \#175 http://agroforestry.net/overstoryback.../97-overstory-175-deep-pipeirrigation. (March 2014) 2006.

[18] Ali E. Study on Stability and Vegetative Growth of Date Palm in the Different Irrigation Treatments. International Journal of Agriculture and Crop Sciences, 2013;1:241-248.

[19] Al-Amoud A.I. Date palm response to subsurface drip irrigation. The Canadian society for Bioengineering, 2006; Paper No. 06-204.

[20] Al-Amoud A.I. Performance of bubbler irrigation system as compared to trickle for large size date palm tree farm. The Canadian Society for Bioengineering, 2008, Paper No. CSBE 08-172.

[21] Mazahrih NTh, AL-Zu'bi Y, Ghnaim H, Lababdeh L, Ghananeem M, Abu-Ahmadeh H. Determination actual evapotranspiration and crop coefficients of date palm trees (Phoenix dactylifera) in the Jordan Valley. American-Eurasian Journal of Agricultural and Environmental Sciences, 2012;12: 434-443.

[22] Mohebi AH. Effects of water use in drip irrigation and surface irrigation methods on yield and vegetative characteristics on date palm. In Proceedings of the International Conference on Mango and Date Palm: Culture and Export, 2005, 20-23 June, University of Agriculture, Faisalabad, Pakistan.

[23] Al-Amoud A.I. and Al-Saud M.I. Subsurface drip irrigation for date palm trees to conserve water. Journal of Saudi Society for Agricultural Science, 2011;10 (1a), 94-120.

[24] Al-Zahrani K.H., Al-Shayaa M.S. and Baig M.B. Water conservation in the Kingdom of Saudi Arabia for better environment: implications for extension and education. Bulgarian Journal of Agricultural Science, 2011;17(3),389-395.

[25] Atta R.; Boutraa T. and Akhkha A. Smart irrigation system for wheat in Saudi Arabia using wireless sensors network technology. International Journal of Water Resources and Arid Environments, 2011;1(6), 478-482. 